\title{
Pemetaan dan Analisis Faktor Risiko Leptospirosis
}

\author{
Mapping and Risk Analysis Factors of Leptospirosis At Banyumas District
}

\author{
Dwi Sarwani Sri Rejeki, Sri Nurlaela, Devi Octaviana
}

Jurusan Kesehatan Masyarakat Fakultas Kedokteran dan Ilmu-ilmu Kesehatan Universitas Jenderal Soedirman

\begin{abstract}
Abstrak
Sampai dengan tahun 2013 dilaporkan ada 13 kasus leptospirosis di Kabupaten Banyumas. Terjadinya peningkatan kasus selama dua tahun terakhir perlu mendapat perhatian dari berbagai pihak agar kasus leptospirosis bisa segera ditangani. Tujuan penelitian ini adalah memetakan kasus leptospirosis dan menganalisis faktor risiko lingkungan dan perilaku yang memengaruhi leptospirosis. Penelitian ini menggunakan desain studi observasional kasus kontrol. Pengumpulan data dilakukan dengan wawancara, observasi, dan pengukuran. Analisis data menggunakan analisis spasial, analisis univariat, dan bivariat. Kasus adalah penderita leptospirosis berjumlah 13 orang dan kontrol adalah tetangga kasus yang tidak menderita leptospirosis berjumlah 52 orang. Hasil pemetaan menunjukkan kasus leptospirosis di Kabupaten Banyumas termasuk daerah aliran sungai dengan radius 600 meter ke sungai; seluruh kasus dekat dengan sawah (jarak $<1 \mathrm{~km}$ ); sebagian besar memiliki vegetasi $\geq 3$ jenis dan berada di daerah dengan curah hujan tinggi. Faktor lingkungan yang terbukti berhubungan dengan leptospirosis adalah kondisi jalan yang buruk sekitar rumah $(\mathrm{OR}=4,90 ; \mathrm{Cl} 95 \%=1,35-17,10)$. Faktor perilaku yang berhubungan dengan leptospirosis adalah kebiasaan mandi/mencuci di sungai $(\mathrm{OR}=4,35 ; 95 \% \mathrm{Cl}=1,21-15,60)$, riwayat peran serta dalam kegiatan sosial yang beresiko $(\mathrm{OR}=12,00 ; 95 \% \mathrm{Cl}=1,45-99,09)$ dan penggunaan alat pelindung diri $(\mathrm{OR}=7,50 ; 95 \% \mathrm{Cl}=1,00-62,18)$.

Kata kunci: Leptospirosis, lingkungan, pemetaan, perilaku
\end{abstract}

\section{Abstract}

There were 13 Leptospirosis cases in Banyumas in 2013. The increasing incidents in last 2 years should get an attention from all institutions. The study conducted was to map incidence of leptospirosis and analyze the environmental and behavior risk factors which associated leptospirosis case. This research was observational by case-control approach. The data was collected through interviews, observation and test. For analyzing the data, the researcher applied spatial analysis, univariate, and bivariate analy- sis. It was 13 leptospirosis cases and 52 people as the controls; they are the neighbors who are free from leptospirosis. The mapping showed that leptospirosis cases in Banyumas were along the riverin 600 meters radius, all cases with the distance of $0-1 \mathrm{~km}$ into the rice field, had vegetation $\geq 3$ species and those were in areas with high rainfall intensity. Environmental risk factor associated with leptospirosis was a bad road conditions around the house (OR =4,90; $\mathrm{Cl} 95 \%=1,35-17,10)$. Behavior risk factors werethe bathing/washing habit in the river $(\mathrm{OR}=4,35 ; 95 \% \mathrm{Cl}$ $=1,21-15,60$, a history of participation in social activities $(\mathrm{OR}=12,00 ; 95 \%$ $\mathrm{Cl}=1,45-99,09)$ and the use of personal protective equipment $(\mathrm{OR}=7,50$; $95 \% \mathrm{Cl}=1,00-62,18)$.

Keywords: Leptospirosis, environment, mapping, behavior

\section{Pendahuluan}

Leptospirosis adalah infeksi akut yang disebabkan oleh bakteri leptospira. Penyakit ini disebut juga Weil disease, Canicola fever, Hemorrhagic jaundice, Mud fever atau Swineherd Disease. Penyakit ini terjadi di seluruh dunia, baik di negara berkembang, negara maju, daerah pedesaan, maupun perkotaan. Leptospirosis ditularkan melalui kontak dengan air, tanah, dan lumpur yang tercemar bakteri leptosipra; kontak dengan organ, darah dan urine hewan yang terinfeksi; serta mengonsumsi makanan yang terkontaminasi. ${ }^{1}$ Menurut Profil Data Kesehatan Indonesia tahun 2011 leptospirosis di Indonesia 3 tahun terakhir (2009 - 2011) cenderung mengalami peningkatan, baik dari jumlah kasus maupun kematian. Dilaporkan bahwa tahun 2011, jumlah kasus

Alamat Korespondensi: Dwi Sarwani Sri Rejeki, Jurusan Kesehatan Masyarakat FKIK Unsoed, Jl. Dr. Suparno Kampus Karangwangkal Purwokerto, Hp. 081328581788,e-mail: dwisarwanisr@yahoo.com 
sebanyak 857 orang, meninggal 82 orang, dan crude fertility rate (CFR) 9,57\%. Provinsi Jawa Tengah adalah penyumbang kedua untuk jumlah kasus (184 orang) dan kematian (33 orang) setelah Provinsi Daerah Istimewa Yogyakarta. ${ }^{2}$ Faktor lingkungan dan perilaku manusia merupakan faktor yang sangat berpengaruh pada kejadian leptospirosis. Hasil penelitian Rejeki, ${ }^{3}$ di Semarang, faktor lingkungan sangat berpengaruh terhadap kejadian leptospirosis berat yaitu adanya sampah di dalam rumah, curah hujan yang tinggi, jarak rumah dan selokan yang dekat.

Analisis spasial terhadap faktor risiko lingkungan menunjukan sebagian besar kejadian leptospirosis terjadi di lokasi dengan kepemilikan hewan peliharaan, di lokasi dengan keberadaan tikus di sekitar rumah, dan terjadi di lokasi dengan tiga jenis vegetasi atau lebih. Sementara itu, kejadian leptospirosis belum terbukti terjadi di lokasi yang terdapat keberadaan parit/selokan. ${ }^{4}$ Faktor risiko lingkungan fisik terkait sebaran leptospirosis antara lain pemukiman, area luasan banjir, ketinggian tempat, curah hujan, tekstur tanah, indeks kerapatan vegetasi serta temperatur, dan kelembapan. ${ }^{5}$

Faktor perilaku yang terbukti berhubungan dengan kejadian leptospirosis antara lain riwayat kontak dengan tikus, hewan peliharaan seperti anjing, kerbau, sapi, perawatan luka, penggunaan alat pelindung diri, kebiasaan mandi atau mencuci di sungai.6-13 Selain itu riwayat kontak dengan genangan air juga terbukti sebagai faktor risiko kejadian leptospirosis karena bakteri leptospira dapat bertahan hidup di air sampai sekitar satu bulan terutama dalam air tawar. Seseorang terinfeksi leptospirosis setelah berenang, piknik di luar rumah, kerja bakti membersihkan genangan air atau berkebun. ${ }^{1,14}$

Di kabupaten Banyumas, pada kurun waktu tahun 2007 - 2009, tidak dilaporkan kasus leptospirosis. Peningkatan kasus terjadi pada tahun 2010 - 2012, kejadian delapan kasus leptosprosis baru merupakan hal yang perlu diwaspadai sebagai kewaspadaan dini agar jangan sampai terjadi wabah leptospirosis. Jumlah kasus leptospirosis yang cenderung meningkat dari tahun sebelumnya dan pemetaan kasus juga belum dilakukan maka perlu dilakukan pemetaan dan identifikasi faktor risiko sehingga bisa dijadikan dasar dalam upaya pengendalian dan pemberantasan penyakit leptospirosis di Kabupaten Banyumas.

Penelitian ini bertujuan untuk melakukan pemetaan dan menganalisis faktor risiko lingkungan (keberadaan genangan air, keberadaan sampah, jarak rumah dengan selokan, kondisi jalan di sekitar rumah, dan keberadaan tikus di dalam dan sekitar rumah, kepemilikan hewan peliharaan sebagai hospes perantara) dan faktor risiko perilaku (riwayat adanya luka, kebiasaan memakai alas kaki, kebiasaan mandi/mencuci di sungai, riwayat peran serta dalam kegiatan sosial yang berisiko leptospirosis, penggunaan alat pelindung, dan pekerjaan) yang memengaruhi kejadian leptospirosis.

\section{Metode}

Penelitian observasional dengan pendekatan kasus kontrol ini dilaksanakan pada bulan Maret - Agustus 2013 di Kabupaten Banyumas. Variabel penelitian ini adalah kejadian leptospirosis, keberadaan genangan air, keberadaan sampah, jarak rumah dengan selokan, kondisi jalan sekitar rumah, keberadaan tikus di dalam dan sekitar rumah, kepemilikan hewan peliharaan sebagai hospes perantara, riwayat luka, kebiasaan memakai alas kaki, kebiasaan mencuci/mandi di sungai, riwayat peran serta dalam kegiatan sosial yang berisiko leptospirosis, penggunaan alat pelindung diri, dan pekerjaan. Populasi adalah penduduk yang bermukim di Kabupaten Banyumas. Kasus adalah semua penderita leptospirosis yang ditemukan dan tercatat di Kabupaten Banyumas. Kriteria inklusi kasus adalah penderita leptospirosis secara klinis dan konfirmasi laboratorium, bermukim di Kabupaten Banyumas dan bersedia menjadi peserta penelitian. Kriteria eksklusi adalah telah pindah rumah di luar Kabupaten Banyumas dan sudah tiga kali didatangi untuk diwawancarai tetapi tidak ada. Kontrol adalah semua tetangga kasus yang didiagnosis tenaga kesehatan tidak menderita leptospirosis dengan kriteria eksklusi tidak bersedia menjadi peserta penelitian. Sampel dalam penelitian ini adalah semua kasus leptospirosis baru yang terdeteksi di Kabupaten Banyumas tahun 2010 - 2013, berjumlah 13 kasus. Kontrol menggunakan perbandingan maksimal yaitu kasus : kontrol adalah $1: 4$ sehingga dibutuhkan 52 kontrol. Jumlah keseluruhan sampel adalah 65. Kelemahan studi ini yaitu tidak melakukan analisis topografi, suhu, dan kelembapan karena keterbatasan peneliti.

Sumber data yang digunakan adalah data primer berupa leptospirosis, data faktor risiko lingkungan, dan data faktor risiko perilaku. Data lokasi leptospirosis diperoleh melalui pengukuran menggunakan instrumen GPS. Faktor risiko lingkungan diperoleh melalui observasi menggunakan instrumen checklist, sedangkan data faktor risiko perilaku diperoleh melalui wawancara menggunakan instrumen kuesioner. Data sekunder berupa jumlah kasus leptospirosis beserta keterangan identitas kasus diperoleh dari data sekunder Dinas Kesehatan Kabupaten Banyumas. Analisis data yang digunakan adalah analisis spasial, analisis univariat, dan bivariat untuk mengetahui nilai odds ratio (OR). Analisis univariat dilakukan pada masing-masing variabel untuk mengetahui proporsi dari masing-masing kasus dan kontrol, ada/ tidaknya perbedaan antara kedua kelompok penelitian. Analisis bivariat dilakukan untuk mengetahui hubungan 2 variabel dan menghitung OR berdasarkan tabel $2 \times 2$ pada tingkat kepercayaan 0,05 dan CI 95\% $(\alpha=0,05)$. 
Pada analisis ini dapat diketahui variabel mana yang terbukti sebagai faktor risiko leptospirosis di Kabupaten Banyumas.

Hasil

Karakteristik responden digambarkan berdasarkan usia, jenis kelamin, dan pendidikan. Rata-rata umur responden kelompok kasus adalah $22 \pm 3,1$ tahun hampir sama pada kelompok kontrol yaitu 21,7 $\pm 1,5$ tahun. Pada kelompok kasus, usia responden yang termuda adalah 11 tahun dan yang tertua adalah 45 tahun. Pada kelompok kontrol, usia responden yang termuda adalah 8 tahun dan yang tertua adalah 50 tahun. Jenis kelamin responden pada kelompok kasus dan kontrol sama yaitu sebagian besar adalah laki-laki (76,9\%). Pendidikan responden pada kelompok kasus terbanyak tamat SD $(46,2 \%)$ sedangkan kelompok kontrol terbanyak adalah tamat SMP $(30,8 \%)$.

Di Kabupaten Banyumas, selama 4 tahun dari tahun 2010 sampai 2013 dilaporkan ada 13 kasus leptospirosis. Setiap kecamatan rata-rata hanya ada 1 kasus leptos- pirosis selama tahun 2010 - 2013, yaitu Kecamatan Kebasen, Purwojati, Gumelar, Kembaran, Banyumas, Rawalo, Ajibarang, Pekuncen dan Cilongok. Kecamatan Sumpiuh ada 4 kasus leptospirosis selama tahun 2010 2013 dan Dinas Kesehatan Kabupaten Banyumas menyatakan KLB pada kasus leptospirosis di Kecamatan Sumpiuh karena kasusnya terjadi pada satu keluarga ada 3 penderita pada tahun 2013.

Kasus leptospirosis di Kabupaten Banyumas termasuk daerah aliran sungai, baik sungai besar maupun cabang sungai. Pada pengukuran buffer jarak kasus dengan sungai besar dikategorikan pada radius 300 meter, 600 meter, 900 meter, dan > 900 meter. Hasil pengukuran menunjukkan ada 1 kasus $(7,7 \%)$ yang radius dari sungai 300 meter, ada 6 kasus $(46,1 \%)$ dengan radius 600 meter, ada 6 kasus $(46,2 \%)$ yang radius dari sungai 900 meter dan $>900$ meter (Gambar 1).

Dari 13 kasus leptospirosis yang dilaporkan, semua kasus menunjukkan berada pada jarak/radius $0-1 \mathrm{~km}$ dari sawah. Terkesan bahwa kasus leptospirosis berhubungan dengan jarak rumah ke sawah, semakin dekat

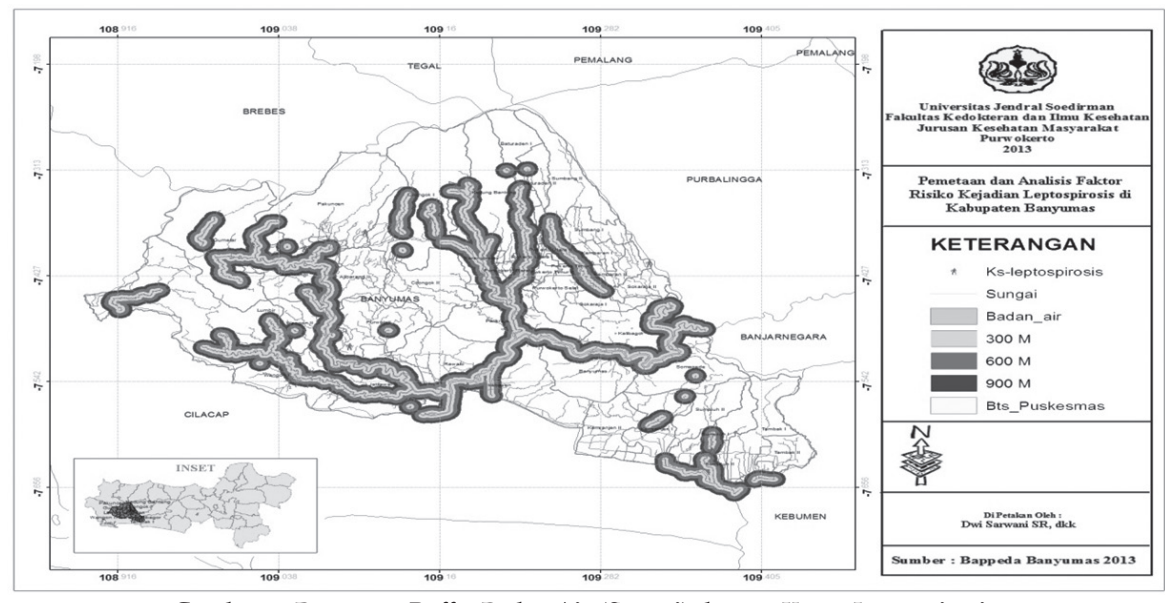

Gambar 1. Pemetaan Buffer Badan Air (Sungai) dengan Kasus Leptospirosis

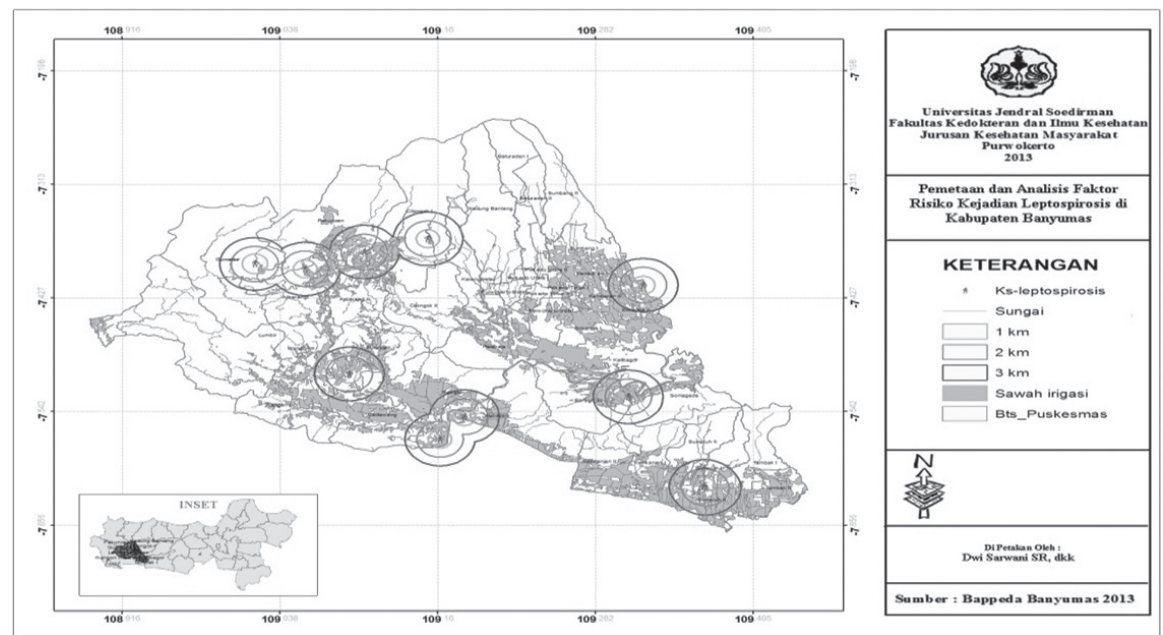

Gambar 2. Pemetaan Buffer Sawah dengan Kasus Leptospirosis 

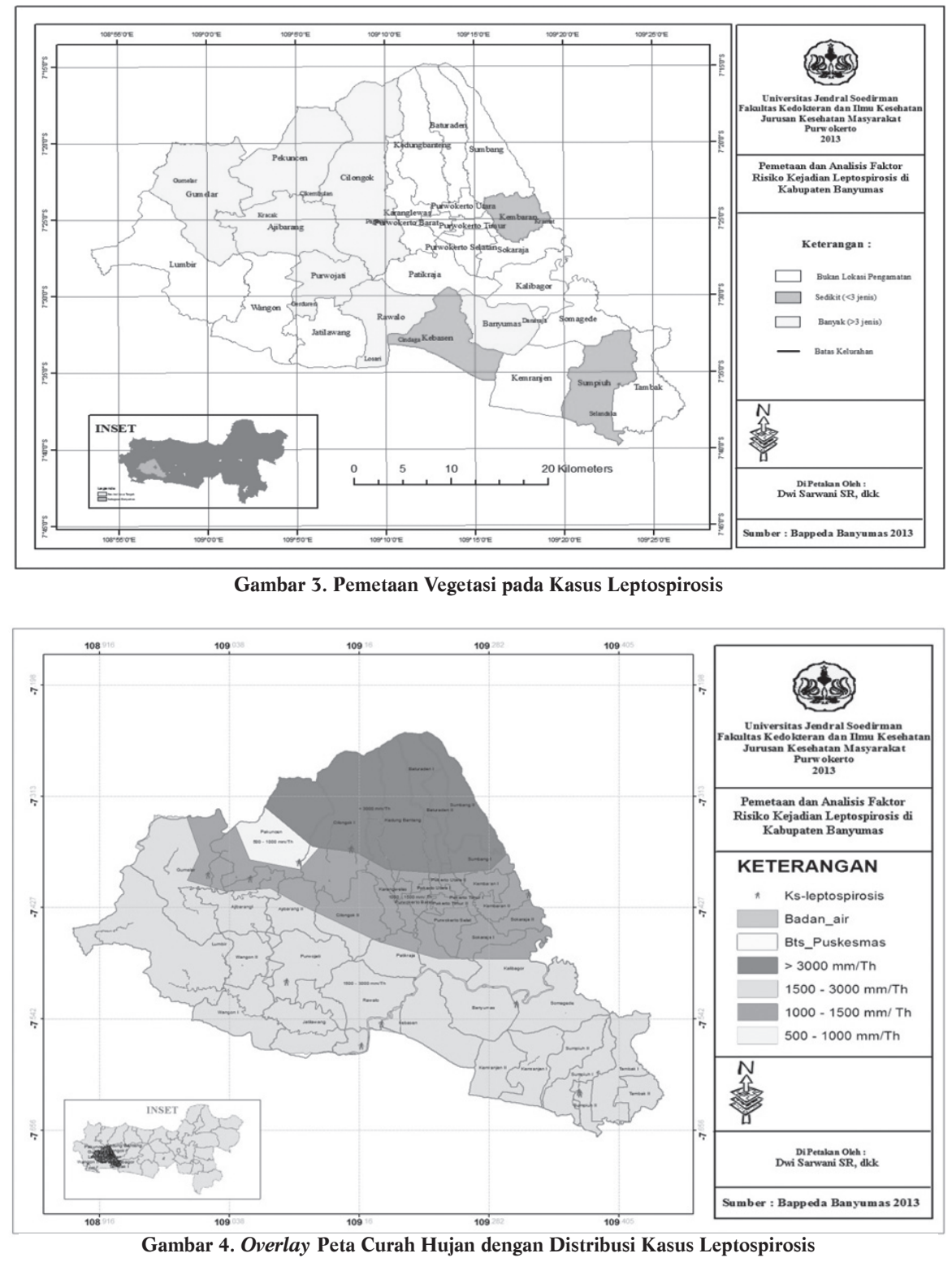

jarak rumah ke sawah semakin berisiko terkena leptospirosis (Gambar 2).

Hasil penelitian menunjukkan bahwa terdapat 53,8\% pada kasus leptospirosis mempunyai vegetasi $\geq 3$ jenis. Vegetasi yang ada di sekitar kasus leptospirosis di Kabupaten Banyumas antara lain sawah (padi dan singkong), semak-semak, pepohonan ranting, hutan heterogen. Wilayah yang memiliki vegetasi $\geq 3$ jenis sebanyak 7 kecamatan, dan 3 kecamatan yang memiliki vegetasi $<3$ jenis (Gambar 3).

Sebaran delapan kasus leptospirosis berada pada daerah dengan curah hujan tinggi, yaitu $1.500-3.000$ $\mathrm{mm} /$ tahun, ada di Kecamatan Purwojati, Banyumas, Kebasen, Rawalo, dan Sumpiuh. Kasus yang berada di daerah dengan curah hujan sedang yaitu $1.000-1.500$ $\mathrm{mm} /$ tahun sebanyak empat kasus yaitu Kecamatan Gumelar, Ajibarang, Cilongok dan Kembaran. Kasus yang berada pada daerah dengan curah hujan rendah yaitu $500-1.000 \mathrm{~mm} /$ tahun hanya ada satu kasus yaitu di Kecamatan Pekuncen (Gambar 4).

Berdasarkan Tabel 1 terlihat bahwa untuk keberadaan genangan air di sekitar rumah baik pada kelompok kasus maupun kelompok kontrol sebagian besar tidak di-temukan adanya genangan air. Bakteri leptospira hidup di air, tanah atau lumpur di sekitar manusia. Keberadaan sampah merupakan tempat reservoir tikus mencari makanan, ditemukan sebagian besar kasus $(84,6 \%)$ terdapat sampah di sekitar rumah. Sebagian besar responden mempunyai jarak selokan $\geq 2$ meter dari rumahnya. Jika selokan rumah terlalu dekat dengan 
Tabel 1. Distribusi Frekuensi Faktor Risiko Leptospirosis

\begin{tabular}{|c|c|c|c|c|c|}
\hline Faktor Risiko & Kategori & Kasus & Persentase $(\%)$ & Kontrol & Persentase $(\%)$ \\
\hline \multirow[t]{2}{*}{ Keberadaan genangan air } & Ada genangan & 5 & 58,5 & 18 & 61,5 \\
\hline & Tidak ada & 8 & 35,4 & 34 & 64,6 \\
\hline \multirow[t]{2}{*}{ Keberadaan sampah } & Ada sampah & 11 & 84,6 & 41 & 78,8 \\
\hline & Tidak ada & 2 & 15,4 & 11 & 21,2 \\
\hline \multirow[t]{2}{*}{ Jarak rumah ke selokan } & $<2$ meter & 3 & 23,1 & 19 & 36,5 \\
\hline & $\geq 2$ meter & 10 & 76,9 & 33 & 63,5 \\
\hline \multirow[t]{2}{*}{ Kondisi jalan sekitar rumah } & Buruk & 7 & 53,8 & 10 & 19,2 \\
\hline & Baik & 6 & 46,2 & 42 & 80,8 \\
\hline \multirow[t]{2}{*}{ Keberadaan tikus sekitar rumah } & Ada tikus & 12 & 92,3 & 44 & 84,6 \\
\hline & Tidak ada & 1 & 7,7 & 8 & 15,4 \\
\hline \multirow[t]{2}{*}{ Kepemilikan hewan peliharaan } & Ada & 3 & 23,1 & 29 & 55,8 \\
\hline & Tidak ada & 10 & 76,9 & 23 & 44,2 \\
\hline \multirow{2}{*}{ Riwayat luka } & Ada luka & 6 & 46,2 & 21 & 40,4 \\
\hline & Tidak ada & 7 & 53,8 & 31 & 59,6 \\
\hline \multirow[t]{2}{*}{ Kebiasaan mandi/mencuci di sungai } & Ya & 7 & 53,8 & 11 & 21,2 \\
\hline & Tidak & 6 & 46,2 & 41 & 78,8 \\
\hline \multirow[t]{2}{*}{ Riwayat kegiatan sosial berisiko } & Ada & 12 & 92,3 & 26 & 50,0 \\
\hline & Tidak ada & 1 & 7,7 & 26 & 50,0 \\
\hline \multirow[t]{2}{*}{ Penggunaan alat pelindung diri } & Tidak memakai & 12 & 92,3 & 32 & 61,5 \\
\hline & Memakai & 1 & 7,7 & 20 & 38,5 \\
\hline \multirow[t]{2}{*}{ Pekerjaan } & Berisiko & 5 & 38,5 & 11 & 21,2 \\
\hline & Tidak berisiko & 8 & 61,5 & 41 & 78,8 \\
\hline
\end{tabular}

Tabel 2. Rangkuman Analisis Bivariat

\begin{tabular}{llll}
\hline Variabel & $\mathbf{n}$ & OR & $\mathbf{9 5 \%} \mathbf{C I}$ \\
\hline Keberadaan genangan air & 1,000 & 1,28 & $0,34-4,14$ \\
Keberadaan sampah & 1,000 & 1,48 & $0,28-7,66$ \\
Jarak rumah-selokan & 0,516 & 0,52 & $0,13-2,113$ \\
Kondisi jalan sekitar rumah & 0,029 & 4,90 & $1,35-17,80$ \\
Keberadaan tikus di dalam dan sekitar rumah & 0,674 & 2,18 & $0,25-19,20$ \\
Kepemilikan hewan peliharaan & 0,072 & 0,24 & $0,06-0,97$ \\
Riwayat luka & 0,950 & 1,26 & $0,37-4,30$ \\
Kebiasaan mencuci/mandi di sungai & 0,034 & 4,35 & $1,21-15,60$ \\
Riwayat peran serta dalam kegiatan social & 0,014 & 12,00 & $1,45-99,0$ \\
Penggunaan APD & 0,46 & 7,50 & $1,00-62,18$ \\
Pekerjaan & 0,279 & 2,33 & $0,63-8,55$ \\
\hline
\end{tabular}

rumah, air selokan akan mudah masuk rumah. Hal ini berisiko menularkan leptospirosis. Kondisi jalan di sekitar rumah kasus lebih banyak yang buruk, yaitu jalan berlubang dan tergenang air jika ada hujan, sedangkan pada kelompok kontrol sebagian besar kondisinya lebih baik. Keberadaan tikus lebih banyak ditemukan pada rumah kasus. Tikus merupakan reservoir utama penyakit leptospirosis. Baik pada kelompok kasus maupun pada kelompok kontrol lebih banyak yang tidak memiliki riwayat adanya luka tiga minggu sebelum terjadinya sakit leptospirosis. Kelompok kasus dan kontrol samasama memiliki kebiasaan mandi atau mencuci di sungai. Kontak dengan air yang mengandung bakteri leptospira pada saat mandi atau mencuci di sungai merupakan faktor risiko leptospirosis. Riwayat kegiatan sosial berisiko seperti kerja bakti membersihkan selokan atau genangan air ditemukan pada 92,3\% kelompok kasus, dan hanya sebagian kecil saja yang menggunakan alat pelindung diri pada saat beraktivitas tersebut. Alat pelindung diri men- cegah bakteri masuk ke dalam tubuh manusia. Pada variabel pekerjaan, baik kelompok kasus maupun kelompok kontrol bukan merupakan pekerjaan yang berisiko yaitu pelajar, ibu rumah tangga, dan sopir.

Dari 11 variabel yang diteliti, ada 4 variabel yang terbukti berhubungan dengan kejadian leptospirosis di Kabupaten Banyumas, yaitu kondisi jalan sekitar rumah, kebiasaan mencuci/mandi di sungai, riwayat peran serta dalam kegiatan sosial dan penggunaan alat pelindung diri (Tabel 2).

\section{Pembahasan}

Pemetaan Leptospirosis

Leptospirosis di Kabupaten Banyumas pertama kali terjadi di Kecamatan Kebasen pada bulan Mei 2010. Tahun 2010 hanya terdapat satu kasus, tahun 2011 meningkat menjadi 6 kasus, meliputi 1 kasus pada bulan Maret di Kecamatan Purwojati, 1 kasus di bulan Mei di Kecamatan Gumelar, 1 kasus di bulan Juli di Kecamatan 
Kembaran, 1 kasus pada bulan November di Kecamatan Ajibarang dan 2 kasus di bulan Desember yang terjadi di Kecamatan Banyumas dan Rawalo. Tahun 2012 menurun menjadi 3 kasus, meliputi 1 kasus terjadi pada bulan Juli di Kecamatan Sumpiuh, 1 kasus pada bulan Agustus di Kecamatan Pekuncen dan 1 kasus terjadi pada bulan Juni di Kecamatan Cilongok. Tahun 2013 dilaporkan terdapat 4 kasus di bulan Mei yang terjadi di Kecamatan Sumpiuh. ${ }^{15}$

Berdasarkan pemetaan, kasus leptospirosis yang terjadi di Kabupaten Banyumas termasuk daerah aliran sungai, baik sungai besar maupun cabang sungai. Pada pengukuran buffer jarak kasus dengan sungai besar, terdapat 6 kasus $(46,1 \%)$ dengan radius 600 meter (Gambar 1). Analisis spasial menggunakan analisis buffer pada sungai dilakukan dengan pertimbangan bahwa air merupakan salah satu media penularan leptospirosis. Penelitian Sunaryo, ${ }^{5}$ menunjukkan bahwa keberadaan sungai di Kota Semarang juga berpengaruh penting terhadap leptospirosis. Daerah pinggiran sungai di wilayah dataran rendah memiliki kerentanan tinggi terhadap kejadian banjir pada saat musim hujan. Pada tahun 2009, sebaran leptospirosis sebagian besar berada di sekitar sungai pada lingkup buffer 50 meter sampai 300 meter. Sungai yang dekat dengan pemukiman digunakan sebagai faktor risiko karena sungai yang tergenang akibat pembuangan sampah merupakan habitat reservoir seperti tikus. Robertson C, et al, ${ }^{16}$ menyatakan bahwa terdapat korelasi positif antara kejadian leptospirosis dengan dekatnya jarak rumah terhadap sungai. Sawah merupakan salah satu jenis vegetasi yang banyak terdapat di lingkungan sekitar rumah, sawah merupakah salah satu tempat habitat tikus. Hasil analisis spasial menggunakan buffer sawah menunjukkan adanya kecenderungan pola kejadian leptospirosis pada radius 0 - 300 meter, 300 600 meter, 600 - 900 meter, dan > 900 meter dari sawah. Keterkaitan kasus leptospirosis dengan sawah dalam penelitian ini terdapat kemungkinan bahwa responden memiliki pekerjaan petani/buruh tani. Responden memiliki lingkungan dengan vegetasi lebih dari tiga jenis sebanyak $53,8 \%$. Vegetasi yang terdapat di sekitar rumah responden berupa sawah, kebun, semak, dan belukar. Kondisi yang memiliki banyak vegetasi memungkinkan sebagai tempat habitat tikus. Dari hasil observasi, vegetasi sekitar responden sebagian besar adalah padi. Selain tanaman tersebut banyak semak dan perdu yang memungkinkan tikus untuk bersembunyi dan tanaman berdahan seperti pohon mangga dan jati.Vegetasi seperti rerumputan dan semak-semak dibutuhkan tikus sebagai tempat persembunyian/sarang tikus dan sumber pakan alternatif. Pohon berdahan memudahkan tikus rumah dan tikus ladang memasuki rumah dengan memanjat melalui dahan atau ranting yang dekat dengan rumah. Berdasarkan penelitian yang dilakukan oleh Robertson C, et al, ${ }^{16}$ diperoleh hasil bahwa terdapat korelasi positif antara kejadian leptospirosis dengan jumlah vegetasi yang banyak di sekitar rumah.

Berdasarkan analisis spasial curah hujan, sebaran delapan kasus berada pada daerah dengan curah hujan tinggi, yaitu 1.500 - $3.000 \mathrm{~mm} /$ tahun, ada di Kecamatan Purwojati, Banyumas, Kebasen, Rawalo, dan Sumpiuh. Terdapat tiga mekanisme yang dapat digunakan untuk menjelaskan hubungan antara curah hujan dan kejadian leptospirosis. Mekanisme yang pertama adalah meningkatnya curah hujan merupakan kondisi yang optimal bagi tikus untuk bereproduksi sehingga terjadi peningkatan populasi tikus, yang berarti meningkatnya juga kemungkinan terjadinya penularan leptospirosis. ${ }^{17}$ Mekanisme yang ke dua adalah tingginya curah hujan mengakibatkan terjadinya banjir yang membuat banyak tikus keluar dari persembunyiannya dan masuk ke lingkungan perumahan, hal tersebut meningkatkan risiko terjadinya penularan leptospirosis. ${ }^{18}$ Mekanisme yang ketiga adalah adanya perbedaan curah hujan meningkatkan risiko manusia untuk terpapar permukaan air yang telah terkontaminasi bakteri leprospira. ${ }^{19}$ Air hujan yang kemungkinan sudah terkontaminasi bakteri leptospira melalui urine tikus mengalir ke daerah persawahan dan berpotensi untuk menginfeksi orang-orang yang melakukan aktivitas di persawahan. Kasus leptospirosis yang terjadi di Kecamatan Sumpiuh terjadi pada satu keluarga yaitu kakak dan dua adiknya kembar. Kondisi rumah pada keluarga ini berisiko leptospirosis karena saat musim hujan kondisi rumah dalam keadaan banjir. Hasil observasi menunjukkan bahwa keluarga ini tidak menggunakan alat pelindung diri saat kontak dengan air banjir di dalam rumahnya. Kondisi ini diperparah dengan letak rumah yang berdekatan dengan sungai sehingga anak-anak keluarga ini sering berenang di sungai.

\section{Analisis Faktor Risiko Lingkungan dan Perilaku Leptospirosis}

Hasil analisis menunjukkan ada hubungan kondisi jalan sekitar rumah dengan kejadian leptospirosis. Seseorang yang kondisi jalan sekitar rumahnya buruk mempunyai risiko 4,9 kali lebih besar untuk menderita leptospirosis dibandingkan yang kondisi jalan sekitar rumahnya baik. Perubahan lingkungan akibat banjir akan mempercepat penyebaran penyakit leptospirosis, hal ini diakibatkan urine hewan yang terinfeksi bakteri leptospira akan terbawa genangan air dan mencemari lingkungan sekitar rumah pada tempat-tempat yang becek. Hasil penelitian terdahulu menyatakan bahwa kondisi genangan air merupakan faktor risiko leptospirosis. ${ }^{13,20,21}$ Kondisi jalan yang becek dan banyak genangan sebagai tempat hidup bakteri leptospira di alam. Bakteri ini bisa bertahan hidup sampai beberapa bulan di genangan air. Saat manusia kontak dengan genangan air di sekitar rumah tanpa menggunakan alat pelindung diri, bakteri 
bisa menginfeksi tubuh manusia.

Selain itu, berdasarkan hasil analisis terbukti ada hubungan antara kebiasaan mandi/mencuci di sungai. Seseorang yang mempunyai kebiasaan mandi/mencuci di sungai mempunyai risiko 4,35 kali lebih besar untuk terkena leptospirosis dibandingkan yang tidak mempunyai kebiasaan mandi/mencuci di sungai. Adanya hubungan kebiasaan mandi/mencuci di sungai dengan kejadian leptospirosis karena responden kasus memiliki aktivitas berenang dan mandi di sungai ketika sungai meluap di musim kemarau. Responden juga mempunyai kebiasaan memandikan hewan ternak di sungai. Hasil penelitian ini sesuai dengan Anies dkk, ${ }^{13}$ yang menyatakan kebiasaan mandi/mencuci di sungai berisiko 4,52 kali lebih besar untuk terpapar leptospira karena kemungkinan kontak dengan urin binatang bakteri leptospira. Air sungai yang digunakan untuk mandi/mencuci bisa terkontaminasi bakteri leptospira yang dibawa oleh urine tikus atau reservoir lain seperti sapi, kambing. Bakteri leptospira dapat masuk ke dalam tubuh manusia lewat mukosa dan kulit yang lecet/luka.

Riwayat peran serta dalam kegiatan sosial juga terbukti berhubungan dengan kejadian leptotospirosis. Seseorang yang sebelumnya mempunyai riwayat melakukan kegiatan sosial berisiko mempunyai risiko 12 kali lipat untuk terkena leptospirosis dibandingkan yang tidak mempunyai riwayat melakukan kegiatan sosial berisiko. Kegitan sosial yang berisiko yang dilakukan responden seperti kerja bakti membersihkan selokan dan membersihkan lingkungan rumah. Kerja bakti merupakan gerbang awal adanya kontak antara manusia dengan lingkungan terkontaminasi. Pada saat kerja bakti inilah kemungkinan terpapar tumbuh-tumbuhan, peralatan, sampah, tanah, lumpur, air selokan, genangan air, dan berbagai bahan infeksius yang berbahaya bagi kesehatan manusia. Hasil penelitian ini sesuai dengan Brockman et al, ${ }^{14}$ yang menyatakan kegiatan berkebun merupakan faktor risiko leptospirosis.

Terdapat hubungan antara penggunaan APD dengan kejadian leptospirosis. Seseorang yang tidak menggunakan APD saat melakukan aktivitas berisiko mempunyai risiko 2,33 kali lebih besar untuk terkena leptospirosis dibandingkan yang menggunakan APD. Hasil penelitian ini sesuai dengan penelitian Bhardwaj et al, ${ }^{12}$ yang menyatakan berjalan kaki tanpa alas kaki berhubungan dengan kejadian leptospirosis di Kota Surat India. Kebiasaan memakai alas kaki saat bekerja berhubungan dengan kejadian leptospirosis. Melakukan kegiatan berisiko tanpa menggunakan alat pelindung diri seperti sandal, sepatu boots, dan sarung tangan akan memberikan risiko terpapar bakteri leptospira.

\section{Kesimpulan}

Hasil pemetaan menunjukkan bahwa kasus leptospi- rosis di Kabupaten Banyumas sebagian besar mengikuti aliran sungai dengan radius $<600$ meter ke sungai, seluruh kasus dengan jarak $0-1 \mathrm{~km}$ ke sungai, memiliki vegetasi $\geq 3$ jenis dan kasus berada di daerah dengan curah hujan tinggi. Faktor lingkungan yang terbukti berhubungan dengan kejadian leptospirosis di Kabupaten Banyumas adalah kondisi jalan yang buruk sekitar rumah, sedangkan faktor risiko perilaku yang terbukti berhubungan dengan leptospirosis adalah kebiasaan mandi/mencuci di sungai, riwayat peran serta dalam kegiatan sosial yang berisiko, dan penggunaan APD.

\section{Saran}

Bagi masyarakat agar menjaga keadaan jalan sekitar rumah agar tidak tergenang air, dan menutup genangan air di sekitar rumah, menghilangkan kebiasaan mandi/mencuci di sungai, menjaga higiene perorangan dan perilaku hidup bersih dan sehat jika melakukan kegiatan sosial seperti kerja bakti, menggunakan alat pelindung diri seperti sepatu boots dan sarung tangan jika melakukan aktivitas di tempat berair. Dinas kesehatan disarankan melakukan penyebaran informasi mengenai penyakit leptospirosis dan pencegahannya, melakukan monitoring pada aktivitas masyarakat yang berisiko terkena leptospirosis seperti rumah pemotongan hewan, petani, melakukan kerja sama lintas sektor dalam rangka pengendalian tikus.

\section{Daftar Pustaka}

1. Widiyono. Penyakit tropis. Epidemiologi, penularan, pencegahan dan pemberantasannya. Jakarta: Erlangga; 2008

2. Kementerian Kesehatan Republik Indonesia. Profil data kesehatan Indonesia Tahun 2012 [online]. 2012 [diakses tanggal 21 Maret 2013]. Diunduh dalam: http://www.depkes.go.id.

3. Rejeki, DSS. Faktor risiko lingkungan yang berpengaruh terhadap kejadian leprospirosis [Tesis]. Semarang: Universitas Diponegoro; 2005.

4. Febrian F, Solikhah. Analisis spasial kejadian leptospirosis di Kabupaten Sleman Propinsi Daerah Istimewa Yogyakarta Tahun 2011. Kesmas Jurnal Kesehatan Masyarakat Nasional. 2011; 7 (1): 7-14.

5. Sunaryo. Sistem informasi geografis untuk pemetaan dan penentuan zona kerawanan leptospirosis di Kota Semarang. 2009 [diakses tanggal 2 November 2013]. Diunduh dalam: http://eprints.undip.ac.id/19202/1/1OR04-Sunaryo-GIS-Leptospirosis.pdf.

6. Renato BR, Ribeiro SG, Felzemburgh MDR, Santana SF, Mohr S, Mendelez OTXA, et al. Impact of environment and social gradient on leptospira infection in urban slums. Plos Neglected Tropical Disease [serial on the internet]. 2008; [cited 2013 Nov 20]; 2 (4). Available from: http://www.ncbi.nlm.nih.gov/pmc/articles/PMC2292260.

7. Faria MT, Calderwood MS, Athanazio DD, McBride AJA, Hartskeerl RA, Pereira MM, et al. Carriage of leptospira interrogans among domestic rats from an urban setting highly endemic for leptospirosis in Brazil. Acta Tropica [serial on the internet]. 2008 [cited 2013 Nov 30]; 108 (1). Available from: http://www.ncbi.nlm.nih.gov/pmc/articles/PMC2596941. 
8. Felt AS, Wasfy OM, El-Tras FW, Samir A, Rahman AB, Boshra M, et al. Cross-species surveillance of leptospira in domestic and peri-domestic animals in Mahalla City. Am J Trop Med Hyg [serial on the internet]. 2011 [cited 2013 Nov 28]; 84(3): 119-129 . Available from: http://www.ncbi.nlm.nih.gov/pubmed/21363980.

9. Sugunan AP, Vijayachari P, Sharma S, Roy S, Manickam P, Natarajaseenivasan K, et al. Risk factors associated with leptospirosis during an outbreak in middle Andaman India. Indian J Med Res [serial on the internet]. 2009 [cited 2013 Nov 30]: 130. Available from: http://www.ncbi.nlm.nih.gov/pubmed/19700804

10. Victoriano AF, Smythe LD, Barzaga NG, Cavinta LI, Kasai T, Limpakarnjanarat K, et al. Leptospirosis in the Asia Pacific Region. Biomed Infect Dis [serial on the internet]. 2009 [cited 2013 Nov 10]; 9 (47). Available from: http://www.biomedcentral.com/1471-2334/9/$147 /$.

11. Ullmann, Langoni. Interactions between environment, wild animals an human leptospirosis. J Venomous Anim Toxins Trop Dis [serial on the internet]. 2011 [cited 2013 Nov 30]; 17 (2). Available from: http://www.scielo.br/scielo.php?pid=S1678-91992011000200 002\&script $=$ sci_arttext.

12. Bhardwaj P, Kosambiya KJ, Desai KV. A case control study to explore the risk factors for acquisition of leptospirosis in Surat City after flood. Ind J Med Sci [serial on the internet]. 2008 [cited 2013 Nov 10]; 62 (11). Available from:http://www.ncbi.nlm.nih.gov/pubmed/19265232.

13. Anies, Hadisaputro S, Sakundarno AM, Suhartono. Lingkungan dan perilaku pada kejadian Leptospirosis. Media Medika Indonesia. 2009; 43 (6): 306-311

14. Brockmann S, Piechotowski I, Hensley OB, Winter C, Oehme R, Zimmermann $\mathrm{S}$, et al. Outbreak of leptospirosis among triathlon participants in Germany, 2006. BioMed Central Infect Dis [serial on the in- ternet]. 2010 [cited 2013 Nov 30]; 10 (91). Available from: http://www.biomedcentral.com/1471-2334/10/91.

15. Dinas Kesehatan Kabupaten Banyumas. Profil Kesehatan Kabupaten Banyumas. Banyumas

16. Robertson C, Nelson TA, Stephen C. Spatial epidemiology of suspected clinical leptospirosis in Sri Lanka. Epidemiol Infect [serial on the internet]. 2012 [cited 2013 Nov 30]; 140. Available from: http ://www. search.proquest.com.

17. Davis S, Calvet E, Leirs H. Fluctuating rodent populations and risk to humans from rodent-borne zoonoses. Vector-Borne Zoonotic Dis [serial on the internet]. 2005; 5 [cited 2013 Nov 5]. Available from: http://www.ncbi.nlm.nih.gov/pubmed/1641742.

18. Tassinari WS, Pellegrini DC, Sa CB, Reis RB, Ko Al, Carvalho MS, Detection and modeling of case clusters for urban leptospirosis. Trop Med Hygiene [serial on the internet]. 2008 [cited 2013 Nov 30]; 13. Available from: http://www.ncbi.nlm.nih.gov/pubmed/18312472.

19. Dassanayake D, Harith W, Suneth BA, Veranja CL, Thibbotumunuwe ACLP, Bimba LG. Evaluation of surveillance case definitions in the diagnosis of leptospirosis, using the microscopic agglutination test. BMC Infect Dis [serial on the internet]. 2009 [cited 2013 Nov 5]; 9 (48). Available from: http://www.biomedcentral.com/1471-2334/9/48.

20. Riyaningsih, Hadisaputra S, Suhartono. Faktor risiko lingkungan terhadap kejadian leptospirosis di Jawa Tengah (studi kasus di Kota Semarang, Kabupaten Demak dan Pati). Jurnal Kesehatan Lingkungan. 2012; 11(1): 87-94.

21. Svircev Z, Markovic MJ, Vukadinov J, Mikic SS, Ruzic M, Doder R, et al. Leptospirosis distribution related to freshwater habitats in the Vojvodina Region (Republic of Serbia). Sciences in China Series: Life Sciencs [serial on the internet]. 2009 [cited 2013 Nov 30]; 52 (10). Available from:http://www.ncbi.nlm.nih.gov/pubmed/19911133. 